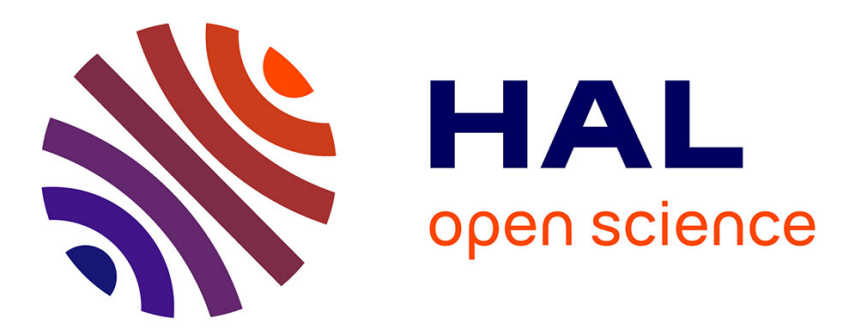

\title{
Crystal structure and formation of TlPd3 and its new hydride TIPd3H
}

Nadine Kurtzemann, Holger Kohlmann

\section{To cite this version:}

Nadine Kurtzemann, Holger Kohlmann. Crystal structure and formation of TlPd3 and its new hydride TIPd3H. Journal of Inorganic and General Chemistry / Zeitschrift für anorganische und allgemeine Chemie, 2010, 10.1002/zaac.201000012 . hal-00599848

\section{HAL Id: hal-00599848 https://hal.science/hal-00599848}

Submitted on 11 Jun 2011

HAL is a multi-disciplinary open access archive for the deposit and dissemination of scientific research documents, whether they are published or not. The documents may come from teaching and research institutions in France or abroad, or from public or private research centers.
L'archive ouverte pluridisciplinaire HAL, est destinée au dépôt et à la diffusion de documents scientifiques de niveau recherche, publiés ou non, émanant des établissements d'enseignement et de recherche français ou étrangers, des laboratoires publics ou privés. 


\section{Crystal structure and formation of TIPd3 and its new hydride TIPd3H}

\begin{tabular}{|r|l|}
\hline Journal: & Zeitschrift für Anorganische und Allgemeine Chemie \\
\hline Manuscript ID: & zaac.201000012.R1 \\
\hline Wiley - Manuscript type: & Article \\
\hline Date Submitted by the \\
Author: & 05-Feb-2010 \\
\hline Complete List of Authors: & $\begin{array}{l}\text { Kurtzemann, Nadine; Universität des Saarlandes, FR 8.1 } \\
\text { Anorganische Festkörperchemie } \\
\text { Kohlmann, Holger; Universität des Saarlandes, FR 8.1 Anorganische } \\
\text { Festkörperchemie }\end{array}$ \\
\hline Keywords: & $\begin{array}{l}\text { hydrides, intermetallic phases, in situ, DSC, neutron powder } \\
\text { diffraction }\end{array}$ \\
\hline
\end{tabular}

\section{s) scholaroNE" \\ Manuscript Central}




\title{
ARTICLE
}

DOI: 10.1002/zaac.200((will be filled in by the editorial staff))

\section{Crystal structure and formation of $\operatorname{TIPd}_{3}$ and its new hydride $\operatorname{TIPd}_{3} \mathrm{H}$}

\author{
Nadine Kurtzemann*, Holger Kohlmann
}

Dedicated to Prof. Dr. Rüdiger Kniep on the occasion of his $65^{\text {th }}$ birthday.

Keywords: hydrides; intermetallic phases; in situ; neutron powder diffraction; DSC

\begin{tabular}{|c|c|}
\hline $\begin{array}{l}\mathrm{TlPd}_{3} \text { was synthesized from the elements in evacuated silica tubes } \\
\text { at } 600^{\circ} \mathrm{C} \text {. Alternatively, TlPd } \mathrm{T}_{3} \text { wielded by reduction of the } \\
\mathrm{TlPd}_{3} \mathrm{O}_{4} \text { in } \mathrm{N}_{2} \text { gas atmosphere. Reduction of the oxide in } \mathrm{H}_{2} \text { gas } \\
\text { atmosphere resulted in the formation of the new hydride } \mathrm{TlPd}_{3} \mathrm{H} \text {. } \\
\text { The structure of tetragonal } \mathrm{TlPd}_{3}\left(\mathrm{ZrAl}_{3} \text { type, space group } I\right. \\
4 / m m m, a=410.659(9) \text { pm, } c=1530.28(4) \mathrm{pm}) \text { was reinvestigated } \\
\text { by X-ray and also by neutron powder diffraction as well as the } \\
\text { structure of its previously unknown hydride } \mathrm{TlPd}_{3} \mathrm{H} \text { (cubic anti- } \\
\text { perovskite type structure, space group } P m 3 m, a=406.313(1) \mathrm{pm} \text { ). }\end{array}$ & $\begin{array}{l}\text { In situ DSC measurements of } \mathrm{TlPd}_{3} \text { in hydrogen gas atmosphere } \\
\text { showed a broad exothermic signal over a wide temperature } \\
\text { range with two maxima at } 280^{\circ} \mathrm{C} \text { and at } 370^{\circ} \mathrm{C} \text { resulting in } \\
\mathrm{TlPd} \mathrm{d}_{3} \mathrm{H} \text { as product. A dependency of lattice parameter of the } \\
\text { intermetallic phase on reaction conditions is observed and } \\
\text { discussed. Results of hydrogenation experiments at room } \\
\text { temperature with gas pressure up to } 280 \text { bar hydrogen and at } \\
\text { elevated temperatures with very low hydrogen gas pressures (1- } \\
2 \text { bar) as well as results of dehydrogenation of the hydrides } \\
\text { under vacuum will be discussed. }\end{array}$ \\
\hline
\end{tabular}




\section{Introduction}

Hydrogen absorption and desorption characteristic of intermetallic compounds and also of noble metals as palladium have been scrutinised with regard to electronic and magnetic properties, hydrogen embrittlement, order-disorder transitions etc. in the past [1-12]. Thereby some of palladium rich compounds with Cu-type superstructures containing e. g. $\mathrm{Mn}[8,13-20], \mathrm{Mg}$ [21-24], $\mathrm{Al}[22,25,31], \mathrm{Ga}$ [22, 26-28, 31], In [27, 29-31], Tl [27, 32-34] or Sn [35] have been explored. Few of the MPd $\mathrm{MP}_{3}$ compounds showed very similar structural changes during hydrogenation forming hydrides $\mathrm{MPd}_{3} \mathrm{H}_{\mathrm{x}}(\mathrm{M}=\mathrm{Mn}, \mathrm{Mg}$ or $\mathrm{In}, \mathrm{x}$ $<1$ ) with a metallic sublattice in the $\mathrm{AuCu}_{3}$-type structure. These intermetallic compounds crystallize in one of the following superstructures of the Cu-type: $\mathrm{AuCu}_{3}, \mathrm{TiAl}_{3}$ or $\mathrm{ZrAl}_{3}$. Our group proposed a gliding mechanism [23] to explain the observed structural changes from the starting structure to the metallic sublattice in the hydride during hydrogen uptake: Comparing configuration and number of octahedral voids in the $\mathrm{AuCu}_{3}$-type structure of $\mathrm{MPd}_{3}$ sublattice with those in the other above mentioned structure types an increase of the voids surrounded by six palladium atoms at the expense of those surrounded by five $\mathrm{Pd}$ and one $\mathrm{M}$ or four $\mathrm{Pd}$ and two $\mathrm{M}$ is realized. Theoretical calculations for $\mathrm{MgPd}_{3}$ show that the preference of hydrogen to occupy octahedral sites with only palladium as nearest neighbour is justified by energetic reasons [24]. Gliding along $1 / 2$ [110] of the domains of antiphases in the $\mathrm{TiAl}_{3}$ - and $\mathrm{ZrAl}_{3}$-types generates the structure of the $\mathrm{AuCu}_{3}$ type which offers more only by palladium atoms encircled octahedral sites to incorporate hydrogen atoms as the larger superstructures [23]. To better understand the relation between the mechanism of the hydride formation and the above mentioned gliding operation along $1 / 2$ [110] it is needful to continue the exploration of hydrogenation behaviour of other palladium rich systems $\mathrm{MPd}_{3}\left(\operatorname{respectively~}^{2}\right.$ $\mathbf{M}_{1-\mathrm{m}} \mathbf{M}_{\mathrm{m}}^{\prime} \mathrm{Pd}_{3}$ ) with Cu-type superstructures, e.g. $\mathbf{M}$ and $\mathbf{M}^{\prime}=\mathrm{Tl}, \mathrm{Pb}, \mathrm{Sn}, \mathrm{In}$.

$\mathrm{TlPd}_{3}$ was reported for the first time by Stadelmaier et al. in 1961 to crystallize in the $\mathrm{SrPd}_{3}$ structure type, a tetragonal distorted variant of the $\mathrm{AuCu}_{3}$ structure (space group $P 4 / \mathrm{mmm}, \mathrm{a}=412 \mathrm{pm}$ and $\mathrm{c}=381 \mathrm{pm}$ ) [32], and later on by Schubert and Bhan et al. $[33,34]$ who determined the crystal structure as $\mathrm{ZrAl}_{3}$-type at room temperature and as $\mathrm{TiAl}_{3}$-type at elevated temperatures. $\mathrm{TlPd}_{3}$ has not yet been examined in respect of its hydrogenation characteristics, till this day. In this work the crystal structure of $\mathrm{TIPd}_{3}$ is examined again by X-ray and neutron powder diffraction, results of hydrogenation and dehydrogenation of $\mathrm{TIPd}_{3}$ are presented and discussed as well as the structure of the new hydride $\mathrm{TlPd}_{3} \mathrm{H}$.

\section{Experimental Section}

\subsection{Synthesis}

$\mathrm{TIPd}_{3}$ powder samples were synthesized form the elements. Palladium (powder $<60 \mu \mathrm{m}, 99.9+\%$, ChemPur or powder, $60 \mu \mathrm{m}, 99,9 \% \mathrm{ABCR}$ ) and thallium (rod, 99.999\%, Alfa Aesar) cut in pieces inside an argon filled glove box were heated in evacuated sealed silica tubes at $600^{\circ} \mathrm{C}$ and typically reground one or more times. The overall reaction time was between 40 and 300 hours. Alternatively the grey intermetallic phase was obtained by decomposition of $\mathrm{TlPd}_{3} \mathrm{O}_{4}$ at $730^{\circ} \mathrm{C}$ in nitrogen atmosphere [36, 37], usually within 12 hours. To gain the cardinal red oxide $\operatorname{TlPd}_{3} \mathrm{O}_{4}[36,37]$ we embarked a solid state synthesis route not afore known for this oxide: Appropriate amounts of the elements palladium and thallium were prepared as mentioned above and heated at $600^{\circ} \mathrm{C}$ in air in silica or corundum crucibles for 24 hours with a regrinding step after 12 hours. The oxide was obtained as main phase with less than $3 \%$ of $\mathrm{TlPd}_{3}$ as byproduct. With a heating time of only 12 hours in air or 6 hours even in pure oxygen mixed phases of $\mathrm{TlPd}_{3} \mathrm{O}_{4}, \mathrm{Tl}_{2} \mathrm{O}_{3}, \mathrm{TlPd}_{3}\left(\mathrm{ZrAl}_{3}\right.$-type), $\mathrm{PdO}$ and $\mathrm{Pd}$ were yielded (which is below called 5-phase-mixture).

The hydride formation was explored either by hydrogenation of the intermetallic phase or by reduction of oxide $\mathrm{TlPd}_{3} \mathrm{O}_{4}$ or of 5-phase-mixture directly in hydrogen atmosphere (Praxair, 99.999\%) in a chamber furnace (Linn HighTherm HT 1400 Vac) with a gas flow rate of $100 \mathrm{ml} / \mathrm{min}$. For both reactions, conditions were typically 12 hours held at $730^{\circ} \mathrm{C}$ and $1 \mathrm{bar}$ hydrogen pressure. The heating rate was $100^{\circ} \mathrm{C} / \mathrm{h}$ or $300^{\circ} \mathrm{C} / \mathrm{h}$, the cooling rate $200^{\circ} \mathrm{C} / \mathrm{h}$ or $300^{\circ} \mathrm{C} / \mathrm{h}$. Few hydrogenation experiments were performed within in an autoclave described elsewhere [31] up to 280 bar hydrogen pressure and a maximum temperature of $250^{\circ} \mathrm{C}$.

\subsection{X-Ray powder diffraction}

Powder X-Ray diffraction (XRPD) patterns were recorded on a Huber image plate Guinier diffractometer G670 using $\mathrm{CuK}_{a 1}$ radiation $(\lambda=154.053 \mathrm{pm})$. The measurements were performed using flat transmission samples with the powders fixed on an adhesive tape. Step width of the data was $0.005^{\circ}$ in $2 \theta$ and silicon was used as internal standard. For Rietveld refinements the programme Full Prof [38] was applied using pseudo-Voigt functions to generate the line shape of the diffraction peaks.

\subsection{Neutron powder diffraction and Rietveld refinement}




\section{Results and Discussion}

\subsection{Structure of $\operatorname{TIPd}_{3}$}

The obtained diffraction data show the pattern of a tetragonal unit cell with $a=410.659(9) \mathrm{pm}$ and $c=1530.28(4) \mathrm{pm}$ for the neutron data. The intensities match to those of the $\mathrm{ZrAl}_{3}$-type structure (space group I4/mmm, No.139; Figure 2a), which is a tetragonally distorted, ordered superstructure of the $\mathrm{Cu}$ structure type [30]. This tetragonal structure type was already proposed by Schubert et al. and Bhan et al. as the room temperature structure for $\operatorname{TlPd}_{3}[33,34]$. The high temperature phase with $\mathrm{TiAl}_{3}$ structure described by Schubert et al. and Bhan et al. [33, 34] was not observed during our experiments. The neutron diffraction pattern given in Figure 1a provide the first refined crystal structure for $\mathrm{TlPd}_{3}$ from neutron data which are in agreement with structure data determined for the same sample by x-ray powder data (see Table 3 ). The lattice parameter reported by Schubert et al. $a=411.7 \mathrm{pm}$ and $c=1527.4 \mathrm{pm} \mathrm{[33]} \mathrm{are} \mathrm{concordantly} \mathrm{to} \mathrm{our} \mathrm{sample} \mathrm{synthesized} \mathrm{from} \mathrm{the}$ elements with a reaction time of 60 hours (Table 3), but differ a bit for them with longer reaction times. However, the c/a ratio for all samples with $\mathrm{ZrAl}_{3}$ structure is 0.93 . Refinement of the free positional z parameters in the two Wyckoff positions $4 e$ of the structure (Table 1) for the neutron data resulted in values close the idealized ones $\mathrm{z}(\mathrm{Tl})=0.125$ and $\mathrm{z}(\mathrm{Pd} 3)=0.375[30]$, for both the deviation is not significant applying the $5 \sigma$ criterion (Table1) but the determined values are similar to those observed by Wannek for $\mathrm{MgPd}_{3}$ owning the same structure type $(\mathrm{z}(\mathrm{Mg})=0.1242(10)$ and $\mathrm{z}(\mathrm{Pd} 3)=0.3742(2))$ [22]. The palladium-palladium distances vary from $277.7(5) \mathrm{pm}$ to $290.4(1) \mathrm{pm}$, the distances for palladium-thallium vary between 279.6(3) pm and 290.4(1) pm, also comparable to the distances known for $\mathrm{MgPd}_{3}\left(\mathrm{ZrAl}_{3}\right.$ type structure) [21, 22] as well as with $\mathrm{InPd}_{3}\left(\mathrm{ZrAl}_{3}\right.$ type structure) [30].

\subsection{Structure of $\operatorname{TIPd}_{3} \mathbf{H}$}

$\mathrm{TlPd}_{3} \mathrm{H}$ was formed as product after reaction of $\mathrm{TlPd}_{3}$ or the oxide phase $\mathrm{TlPd}_{3} \mathrm{O}_{4}$ in hydrogen gas at elevated temperatures (Table 3). From X-ray diffraction data $\mathrm{TlPd}_{3} \mathrm{H}$ was found to crystallize in the cubic space group Pm3m (No.221) [Figure 2b]. The sublattice, which is built by metal atoms, forms a $\mathrm{AuCu}_{3}$ type structure. From neutron data the hydrogen position (Table 2) was determined using difference Fourier analysis. For $\operatorname{TlPd}_{3} \mathrm{H}$ the void is found to be occupied, which is in the centre of the unit cell $\left(1 / 21 / 2 \frac{1}{2}\right)$ and surrounded by six palladium atoms. Refinement of the occupation factor resulted within the standard deviation in total occupation of this hydrogen position, for which reason the occupation parameter was fixed to the value 1 . Beyond this, no significant occupation of the second remaining octahedral site on the edge centre $(1 / 200)$ was found. In comparison to the intermetallic compound the neutron diffraction pattern of the hydride shown in Figure 1b exhibits a slightly enhanced, sloped background due to the incoherent scattering of ${ }^{1} \mathrm{H}$. Nevertheless, because of the high quality of the presented data, Rietveld refinements yielded precise crystal structure parameters thus deuteration was not necessary. The difference between deuterides and hydrides was investigated recently by Henry et al. [40] and Ting et al. [41] and only small variation in structural parameters was observed in general.

The relative volume increase per formula unit $\Delta \mathrm{V} / \mathrm{V}_{0}$ is $3.9(1) \%$ for all completely transformed samples $\mathrm{TlPd}_{3} \mathrm{H}(\mathrm{see} \mathrm{Table}$ 3) and $\Delta \mathrm{V} / \mathrm{V}_{0}=3.6$ or $3.7 \%$ for partially hydrogenated samples with $\mathrm{AuCu}_{3}$ type metal atom sublattice. For the latter this accords to a $\operatorname{TlPd}_{3} \mathrm{H}_{\mathrm{x}}$ phase with $\mathrm{x}$ estimated to be about 0.9 assuming a linear relationship between $\mathrm{x}$ and $\Delta \mathrm{V} / \mathrm{V}_{0}$. This indicates a small homogeneity range with respect to the hydrogen content. 
The formation pathway of $\beta-\mathrm{TlPd}_{3} \mathrm{H}_{\mathrm{x}}$ with as starting material could be topotactical, in case of $\beta-\mathrm{TlPd}_{3} \mathrm{H}_{\mathrm{x}}$ the $\mathrm{TlPd} \mathrm{d}_{3}$ substructure is a $\mathrm{AuCu}_{3}$ type structure (Figure $2 \mathrm{~b}$ ) and in case of $\mathrm{TlPd}_{3} \mathrm{O}_{4}$ it is $2 \times 2 \times 2$ superstructure of the AuCu $\mathrm{A}_{3}$ type structure (Figure 2c). This fact could be the explanation that the amount of $\beta-\mathrm{TlPd}_{3} \mathrm{H}_{\mathrm{x}}$ is higher for $\mathrm{TlPd}_{3} \mathrm{O}_{4}$ as for both other starting materials under same reaction conditions. However it seems more likely that the smaller particle size of the oxide as compared to the intermetallic phase causes the above mentioned enhanced reactivity. Further hydrogenation experiments some of them carried out in the gas pressure cell of the DSC (Section 2.4.) demonstrated that temperatures of $500^{\circ} \mathrm{C}$ and also of $320^{\circ} \mathrm{C}$ for even clearly less then 12 hours suffice to observe the full hydrogenation of $\mathrm{TlPd}_{3}$ in hydrogen gas atmosphere around 1bar. DSC measurements (Figure 3) showed an exothermic reaction during hydrogen absorption over a wide temperature range. The broad exothermic signal has two maxima, one around $280^{\circ} \mathrm{C}$ and a second in the region of $370^{\circ} \mathrm{C}$. These detected maxima could be a hint of a stepwise reaction during hydrogen incorporation as already assumed. Nevertheless DSC measurements up to only $320^{\circ} \mathrm{C}$ and held there for 1 hour resulted in a complete hydrogenated, cubic antiperovskite type structured sample. Since the cooling branches show no signal the hydrogen uptake is not reversible under these conditions. The stability of the hydride at ambient conditions in air over months also was observed (Section 3.2.).

In order to study the thermal stability of $\mathrm{TlPd}_{3} \mathrm{H}_{\mathrm{x}}$ its behaviour under dynamic vacuum and elevated temperature was investigated. Evacuation of the pure $\beta-\mathrm{TIPd}_{3} \mathrm{H}$ samples in the dynamic vacuum $\left(\mathrm{p} \approx 10^{-1} \mathrm{mbar}\right.$ ) over 16 hours at $120^{\circ} \mathrm{C}-130^{\circ} \mathrm{C}$ showed a small volume per formula decrease $(\leq 0.2 \%)$ only, whereas upon reheating to $230^{\circ} \mathrm{C}$ under the same conditions the hydride released hydrogen to rebuild again $\mathrm{TlPd}_{3}$ in the known tetragonal structure (Figure 2a). A $1: 1 \quad \alpha-\mathrm{TlPd}_{3} \mathrm{H}_{\mathrm{x}}$ and $\beta-$ $\mathrm{TlPd}_{3} \mathrm{H}$ sample obtained in an atmosphere of $7.5 \%$ hydrogen in argon (see above) was investigated using the same temperature treatment. The $\alpha-\mathrm{TlPd}_{3} \mathrm{H}_{\mathrm{x}}$ phase showed at $120^{\circ} \mathrm{C}-130^{\circ} \mathrm{C}$ as well as at $230^{\circ} \mathrm{C}$ a volume decrease of $\sim 0.4 \%$ per formula unit. The $\beta-\mathrm{TlPd}_{3} \mathrm{H}$ phase showed similar behaviour as pure $\beta-\mathrm{TlPd}_{3} \mathrm{H}$ samples. In the end this mixed sample also resulted in $\mathrm{TlPd}_{3}\left(\mathrm{ZrAl}_{3}\right.$-type) as single phase (Table 3$)$. 


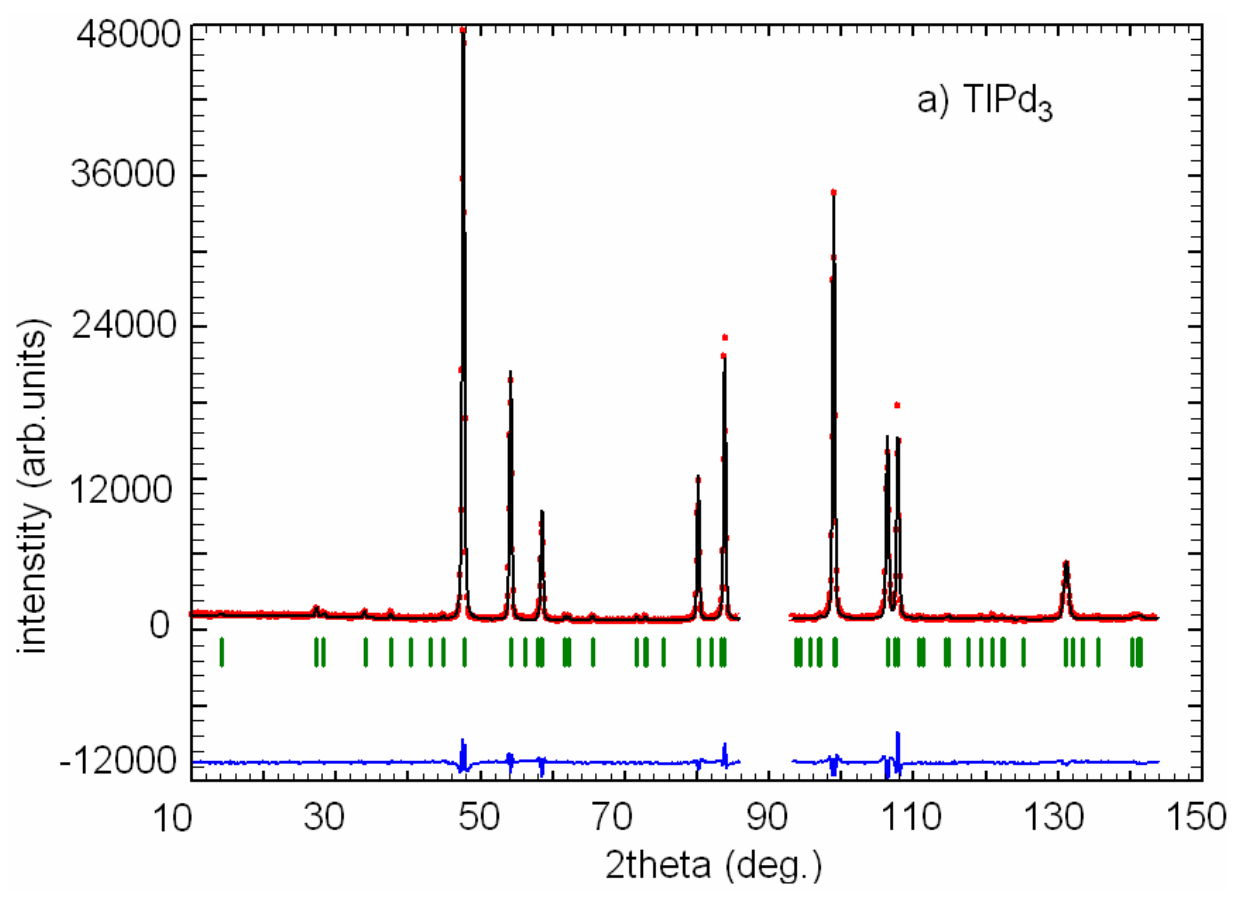

Figure 1a. ((Rietveld refinement on neutron powder diffraction data of $\mathrm{TlPd}_{3}$ (D20 at ILL (Grenoble, France), $\lambda=186.893(2) \mathrm{pm}$, $\mathrm{T}=298(2) \mathrm{K})$. Observed (dots), calculated (solid line) and difference (observed-calculated, bottom) neutron powder diffraction patterns. Bragg peak positions of $\mathrm{TlPd}_{3}$ in the $\mathrm{ZrAl}_{3}$ type structure. Excluded region $86^{\circ} \leq 2 \theta \leq 93^{\circ}$ for Rietveld refinement was chosen because of a contribution to the diffraction pattern caused by the sapphire sample holder))

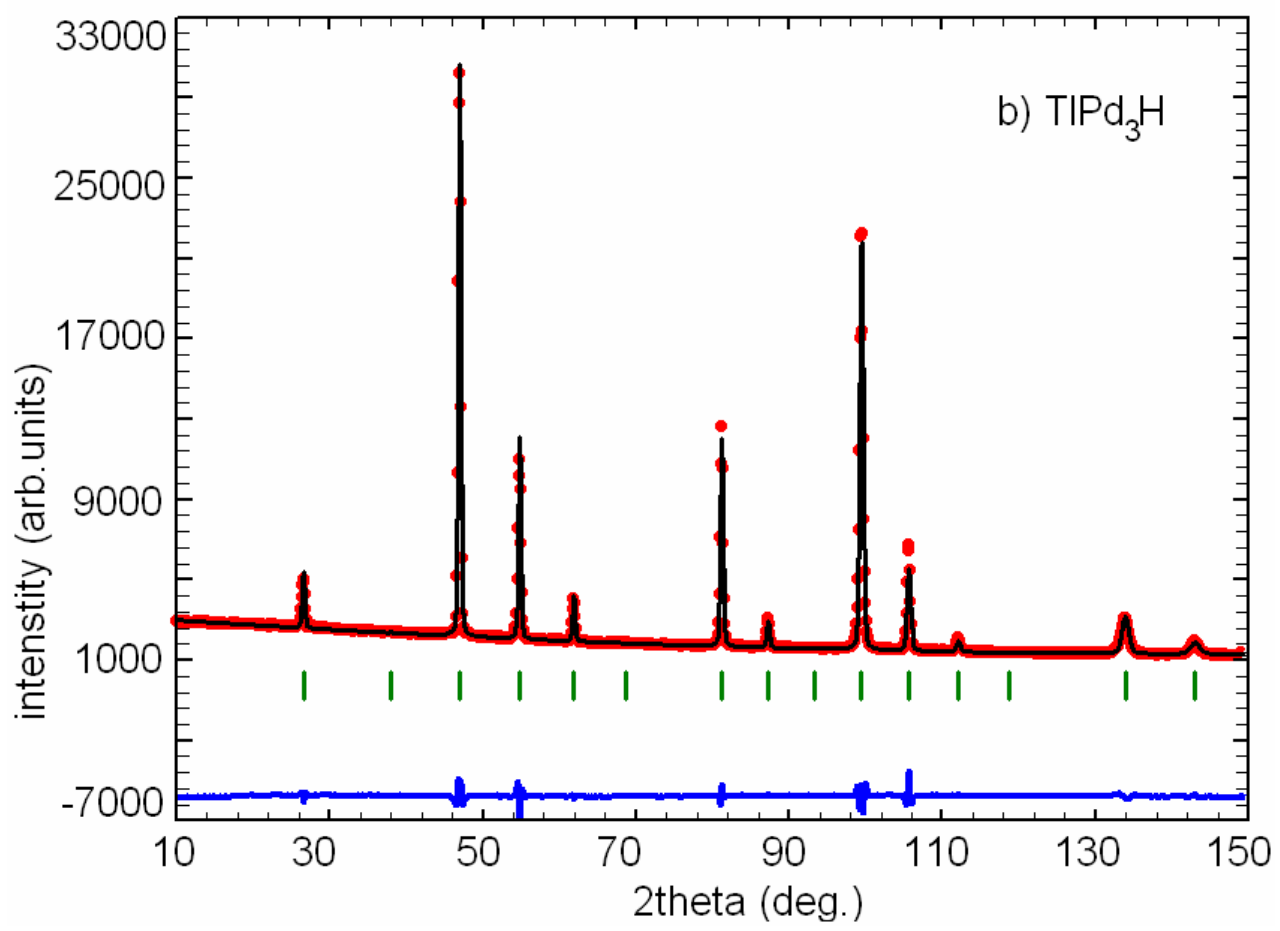


Figure 1b. ((Rietveld refinement on neutron powder diffraction data of $\operatorname{TlPd}_{3} \mathrm{H}$ (D20 at ILL (Grenoble, France), $\lambda=186.893(2) \mathrm{pm}$, $\mathrm{T}=298(2) \mathrm{K}$ ). Observed (dots), calculated (solid line) and difference (observed-calculated, bottom) neutron powder diffraction patterns. Bragg peak positions of $\mathrm{TlPd}_{3} \mathrm{H}$ in the anti-perovskite type structure))

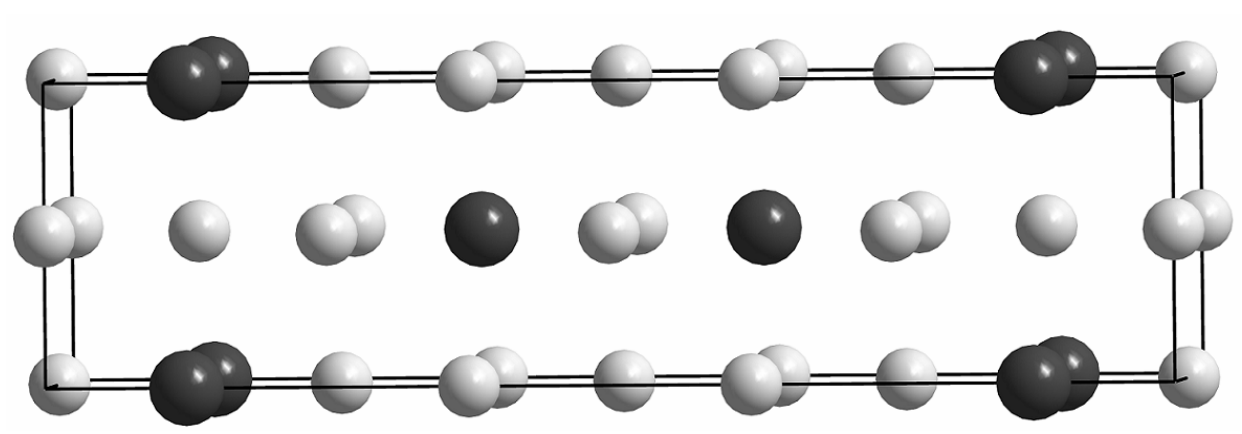

Figure 2a. ((Crystal structure of $\mathrm{TlPd}_{3}\left(\mathrm{ZrAl}_{3}\right.$ type), dark grey spheres represent thallium and bright grey spheres palladium))

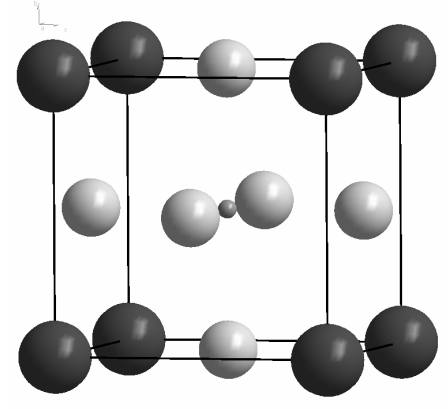

Figure 2b. ((Crystal structure of $\mathrm{TlPd}_{3} \mathrm{H}$ (cubic anti-perovskite type), dark grey spheres represent thallium, bright grey spheres palladium and small middle grey spheres hydrogen))

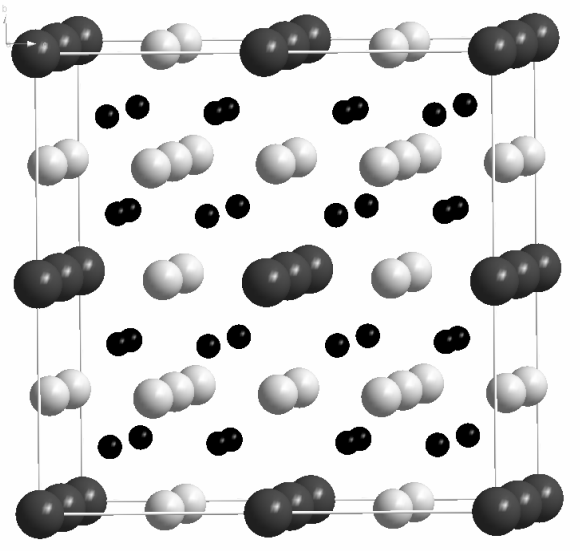


Figure 2c. ( (Crystal structure of $\mathrm{TlPd}_{3} \mathrm{O}_{4}\left(\mathrm{Tl}\right.$ and Pd form a $2 \times 2 \times 2$ superstructure of the $\mathrm{AuCu}_{3}$ structure with oxygen located in one half of the tetrahedral sites) according to Ref. [36], dark grey spheres represent thallium and bright grey spheres palladium and small black spheres oxygen))

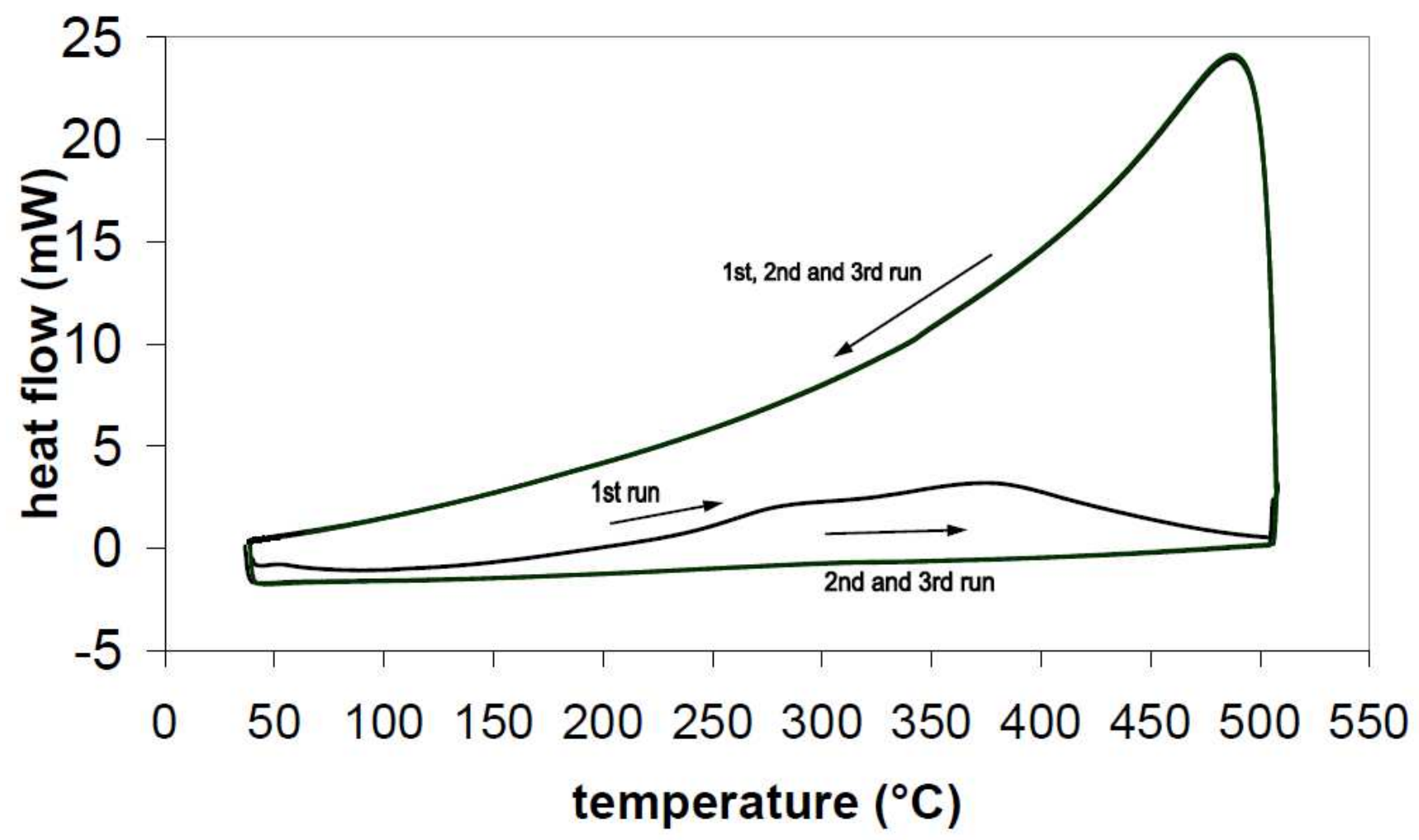

Figure 3. ((DSC curves of $\mathrm{TlPd}_{3}$ under 1.5 bar $\mathrm{H}_{2}$, heating rate $10^{\circ} \mathrm{C} / \mathrm{min}$, exothermic signal up))

Table 1. ((Crystal structure parameters and atomic distances of $\mathrm{TlPd}_{3}$ at room temperature from neutron powder diffraction data space group I4/mmm (No.139): $\left.\left.a=410.659(9) \mathrm{pm}, c=1530.28(4) \mathrm{pm}, V=258.068(11)^{*} 10^{6} \mathrm{pm}^{3}.\right)\right)$

\begin{tabular}{|c|c|c|c|c|c|}
\hline Atom & Site & $\mathrm{x}$ & $\mathrm{y}$ & $\mathrm{z}$ & $B_{\text {iso }} / 10^{4} \mathrm{pm}$ \\
\hline $\mathrm{Tl}$ & $4 e$ & 0 & 0 & $0.1240(3)$ & $0.67(5)$ \\
\hline Pd1 & $4 c$ & 0 & $1 / 2$ & 0 & $0.67(4)$ \\
\hline $\mathrm{Pd} 2$ & $4 d$ & 0 & $1 / 2$ & $1 / 4$ & $\mathrm{~B}_{\text {iso }}(\mathrm{Pd} 1)$ \\
\hline $\mathrm{Pd} 3$ & $4 e$ & 0 & 0 & $0.3778(5)$ & $\mathrm{B}_{\text {iso }}(\mathrm{Pd} 1)$ \\
\hline \multicolumn{4}{|c|}{ Pd1-Pd1: 290.4(1) pm } & \multicolumn{2}{|c|}{ Pd1-Tl: 279.6(3) pm } \\
\hline \multicolumn{4}{|c|}{ Pd1-Pd3: 277.7(5) pm } & \multicolumn{2}{|c|}{ Pd2-Tl: 281.7(3) pm } \\
\hline \multicolumn{4}{|c|}{ Pd2-Pd3: $283.6(3) \mathrm{pm}$} & \multicolumn{2}{|c|}{ Pd3-Tl: 290.4(1) pm } \\
\hline
\end{tabular}

$R_{\mathrm{p}}=0.054, R_{\mathrm{wp}}=0.072, R_{\mathrm{p}}^{\prime}=0.122, R_{\mathrm{wp}}^{\prime}=0.118, R_{\mathrm{Bragg}}=0.031$. Definition of R factors: $R_{\mathrm{p}}=\Sigma\left|\mathrm{y}_{\mathrm{i}}(\mathrm{obs})-\mathrm{y}_{\mathrm{i}}(\mathrm{calc})\right| / \Sigma \mathrm{y}_{\mathrm{i}}(\mathrm{obs}) ; R_{\mathrm{wp}}=\left[\Sigma \mathrm{w}_{\mathrm{i}}\right.$

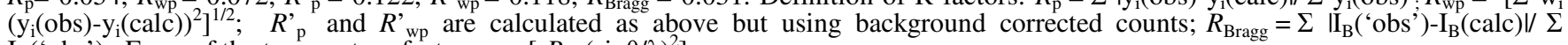

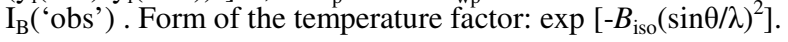

Table 2. ((Crystal structure parameters and atomic distances of $\mathrm{TlPd}_{3} \mathrm{H}$ at room temperature from neutron powder diffraction data space group Pm3m (No.221): $\left.a=406.313(1) \mathrm{pm}, V=67.078(3)^{*} 10^{6} \mathrm{pm}^{3}.\right)$ )

$\begin{array}{llllll}\text { Atom } & \text { Site } & \mathrm{x} & \mathrm{y} & \mathrm{z} & B_{\text {iso }} / 10^{4} \mathrm{pm} \\ \mathrm{Tl} & 1 a & 0 & 0 & 0 & 0.47(5) \\ \mathrm{Pd} & 3 c & 1 / 2 & 1 / 2 & 0 & 0.50(3) \\ \mathrm{H} & 1 b & 1 / 2 & 1 / 2 & 1 / 2 & 2.6(2)\end{array}$

Pd-H: 203.2(1) pm Pd-Tl: 287.(1) pm

$R_{\mathrm{p}}=0.021, R_{\mathrm{wp}}=0.033, R_{\mathrm{p}}^{\prime}=0.143, R_{\mathrm{wp}}^{\prime}=0.103, R_{\mathrm{Bragg}}=0.045$. Defintion of $R_{\mathrm{p}}, R_{\mathrm{wp}}, R_{\mathrm{p}}{ }^{\prime}, R_{\text {wp }}, R_{\mathrm{Bragg}}$ and form of the temperature factor see Table 1 
Table 3. ((Overview of the lattice parameters of $\operatorname{TlPd}_{3}$ and its hydrides determined by $\mathrm{x}$-ray diffraction (labelled with $*$ means determined by neutron diffraction).))

\begin{tabular}{|c|c|c|c|c|c|c|c|c|c|}
\hline $\begin{array}{l}\text { starting } \\
\text { material }\end{array}$ & $\begin{array}{l}\text { T, } \\
\text { time }\end{array}$ & $\mathbf{P}$ (gas) & $\begin{array}{l}\text { Mass } \\
\%\end{array}$ & $\begin{array}{l}\text { Product } \\
\text { phases }\end{array}$ & $\begin{array}{l}\text { Metal } \\
\text { sub- } \\
\text { lattice }\end{array}$ & $\mathbf{a}[\mathrm{pm}]$ & c [pm] & $\begin{array}{l}\text { V (f.u. } \\
\left.\text { TIPd }_{3}\right) \\
{\left[10^{6} \mathbf{p m}^{3}\right]}\end{array}$ & $\begin{array}{l}\Delta \mathrm{V} / \mathrm{V}_{0} \\
{[\%]}\end{array}$ \\
\hline \multirow[t]{3}{*}{$\begin{array}{l}\text { elements } \\
\text { Tl, Pd }\end{array}$} & $\begin{array}{l}600^{\circ} \mathrm{C} \\
160 \mathrm{~h}\end{array}$ & $\begin{array}{l}\text { evacuated } \\
\text { silica tube }\end{array}$ & 100 & $\mathrm{TlPd}_{3}$ & $\overline{\mathrm{ZrAl}_{3}}$ & $410.403(2)$ & $1530.56(1)$ & $64.448(3)$ & -0.1 \\
\hline & $*$ & $*$ & $*$ & $*$ & $*$ & $410.659(9)$ & $1530.28(4)$ & $64.515(1)$ & $0=V_{0}$ \\
\hline & $\begin{array}{l}600^{\circ} \mathrm{C} \\
60 \mathrm{~h}\end{array}$ & $\begin{array}{l}\text { evacuated } \\
\text { silica tube }\end{array}$ & 100 & $\mathrm{TlPd}_{3}$ & $\mathrm{ZrAl}_{3}$ & $411.400(3)$ & $1526.89(2)$ & $64.607(4)$ & +0.1 \\
\hline \multirow[t]{6}{*}{$\mathbf{T I P d}_{3}$} & $\begin{array}{l}730^{\circ} \mathrm{C} \\
12 \mathrm{~h}\end{array}$ & $\mathrm{H}_{2}, 1 \mathrm{bar}$ & 100 & $\beta-T l P d_{3} H$ & $\mathrm{AuCu}_{3}$ & $406.104(4)$ & & $66.975(1)$ & +3.8 \\
\hline & $\begin{array}{l}320^{\circ} \mathrm{C} \\
1 \mathrm{~h}\end{array}$ & $\begin{array}{l}\mathrm{H}_{2} \text {, DSC } \\
1.5 \text { bar }\end{array}$ & 100 & $\beta-T l P d_{3} H$ & $\mathrm{AuCu}_{3}$ & $406.195(5)$ & & $67.020(1)$ & +3.9 \\
\hline & $\begin{array}{l}500^{\circ} \mathrm{C} \\
1 \mathrm{~h}\end{array}$ & $\begin{array}{l}\mathrm{H}_{2}, \text { DSC } \\
1.5 \mathrm{bar}\end{array}$ & 100 & $\beta-T l P d_{3} H$ & $\mathrm{AuCu}_{3}$ & $406.252(2)$ & & $67.048(1)$ & +3.9 \\
\hline & $\begin{array}{l}500^{\circ} \mathrm{C} \\
10 \mathrm{~h}\end{array}$ & $\mathrm{H}_{2}, 1$ bar & 100 & $\beta-T l P d_{3} H$ & $\mathrm{AuCu}_{3}$ & $406.272(4)$ & & $67.058(1)$ & +3.9 \\
\hline & $*$ & $*$ & $*$ & * & $*$ & $406.313(1)$ & & $67.078(3)$ & +3.9 \\
\hline & $\begin{array}{l}730^{\circ} \mathrm{C} \\
12 \mathrm{~h}\end{array}$ & $\begin{array}{l}7.5 \% \mathrm{H}_{2} / \mathrm{Ar} \\
1 \text { bar }\end{array}$ & $\begin{array}{l}86 \\
14\end{array}$ & $\begin{array}{l}\alpha-T_{l P d_{3} H} \\
\beta-T l P d_{3} H\end{array}$ & $\begin{array}{l}\mathrm{ZrAl}_{3} \\
\mathrm{AuCu}_{3}\end{array}$ & $\begin{array}{l}411.133(5) \\
405.84(1)\end{array}$ & $1536.27(3)$ & $\begin{array}{l}64.919(7) \\
66.844(3)\end{array}$ & $\begin{array}{l}+0.6 \\
+3.6\end{array}$ \\
\hline \multirow[t]{3}{*}{$\mathrm{TIPd}_{3} \mathrm{O}_{4}$} & $\begin{array}{l}730^{\circ} \mathrm{C} \\
12 \mathrm{~h}\end{array}$ & $\mathrm{~N}_{2}, 1 \mathrm{bar}$ & 100 & $\mathrm{TlPd}_{3}$ & $\mathrm{ZrAl}_{3}$ & $410.454(3)$ & $1531.05(1)$ & $64.485(4)$ & -0.1 \\
\hline & $\begin{array}{l}730^{\circ} \mathrm{C} \\
12 \mathrm{~h}\end{array}$ & $\begin{array}{l}7.5 \% \mathrm{H}_{2} / \mathrm{Ar} \\
1 \mathrm{bar}\end{array}$ & $\begin{array}{l}18 \\
82\end{array}$ & $\begin{array}{l}\alpha-\operatorname{TlPd}_{3} H \\
\beta-T l P d_{3} H\end{array}$ & $\begin{array}{l}\mathrm{ZrAl}_{3} \\
\mathrm{AuCu}_{3}\end{array}$ & $\begin{array}{l}410.34(3) \\
406.077(6)\end{array}$ & $1544.5(2)$ & $\begin{array}{l}65.018(4) \\
66.962(2)\end{array}$ & $\begin{array}{l}+0.8 \\
+3.8\end{array}$ \\
\hline & $\begin{array}{l}730^{\circ} \mathrm{C} \\
12 \mathrm{~h}\end{array}$ & $\mathrm{H}_{2}, 1$ bar & 100 & $\beta-T l P d_{3} H$ & $\mathrm{AuCu}_{3}$ & $406.092(2)$ & & $66.969(1)$ & +3.8 \\
\hline $\begin{array}{l}5 \text { phase } \\
\text { mixture }\end{array}$ & $\begin{array}{l}730^{\circ} \mathrm{C} \\
12 \mathrm{~h}\end{array}$ & $\begin{array}{l}7.5 \% \mathrm{H}_{2} / \mathrm{Ar} \\
1 \mathrm{bar}\end{array}$ & $\begin{array}{l}64 \\
36\end{array}$ & $\begin{array}{l}\alpha-T l P d_{3} H \\
\beta-T l P d_{3} H\end{array}$ & $\begin{array}{l}\mathrm{ZrAl}_{3} \\
\mathrm{AuCu}_{3}\end{array}$ & $\begin{array}{l}411.351(8) \\
405.980(6)\end{array}$ & $1535.18(4)$ & $\begin{array}{l}64.943(1) \\
66.914(2)\end{array}$ & $\begin{array}{l}+0.7 \\
+3.7\end{array}$ \\
\hline \multirow[t]{2}{*}{$\begin{array}{l}\alpha-\mathrm{TIPd}_{3} \mathrm{H} \\
\beta-\mathrm{TIPd}_{3} \mathrm{H}\end{array}$} & $\begin{array}{l}120- \\
130^{\circ} \mathrm{C} \\
16 \mathrm{~h}\end{array}$ & vacuum & $\begin{array}{l}55 \\
45\end{array}$ & $\begin{array}{l}\alpha-\operatorname{TlPd}_{3} H \\
\beta-T l P d_{3} H\end{array}$ & $\begin{array}{l}\mathrm{ZrAl}_{3} \\
\mathrm{AuCu}_{3}\end{array}$ & $\begin{array}{l}410.695(6) \\
405.804(6)\end{array}$ & 1534.94(3) & $\begin{array}{l}64.725(8) \\
66.827(2)\end{array}$ & $\begin{array}{l}+0.3 \\
+3.6\end{array}$ \\
\hline & $\begin{array}{l}230^{\circ} \mathrm{C} \\
16 \mathrm{~h}\end{array}$ & vacuum & 100 & $\mathrm{TlPd}_{3}$ & $\mathrm{ZrAl}_{3}$ & $410.640(2)$ & $1529.15(2)$ & $64.463(3)$ & -0.1 \\
\hline \multirow[t]{2}{*}{$\beta-\mathrm{TIPd}_{3} \mathrm{H}$} & $\begin{array}{l}120- \\
130^{\circ} \mathrm{C} \\
16 \mathrm{~h}\end{array}$ & vacuum & 100 & $\beta-T l P d_{3} H$ & $\mathrm{AuCu}_{3}$ & $406.033(3)$ & & $66.939(1)$ & +3.6 \\
\hline & $\begin{array}{l}230^{\circ} \mathrm{C} \\
16 \mathrm{~h}\end{array}$ & vacuum & 100 & $\mathrm{TlPd}_{3}$ & $\mathrm{ZrAl}_{3}$ & $410.635(3)$ & $1529.23(2)$ & $64.465(4)$ & -0.1 \\
\hline
\end{tabular}

\section{Conclusion}

Synthesis of $\mathrm{TlPd}_{3}$ from the elements or $\mathrm{TlPd}_{3} \mathrm{O}_{4}$ as starting materials was investigated. The $\mathrm{ZrAl}_{3}$ type structure proposed in literature for the intermetallic compound was confirmed. First structure refinements for $\mathrm{TlPd}_{3}$ were performed and resulted in structural parameters very similar to those of other $\mathrm{MPd}_{3}$ phases $(\mathrm{M}=\mathrm{Mg}$ and $\mathrm{In})$. Formation of $\mathrm{TlPd}_{3} \mathrm{H}_{\mathrm{x}}$ was achieved by reduction of the oxide phase $\mathrm{TlPd}_{3} \mathrm{O}_{4}$ in hydrogen gas atmosphere. The hydrogenation of $\mathrm{TlPd}_{3}$ also resulting in $\operatorname{TlPd}_{3} \mathrm{H}_{\mathrm{x}}$ was studied by NPD, XRPD and in situ DSC. For high pressure of 280 bar no significant hydrogen absorption at room temperature was found, but at $250( \pm 10)^{\circ} \mathrm{C}$. At around 1 bar hydrogen gas pressure, formation of the previously unknown 
hydride $\beta-\mathrm{TlPd}_{3} \mathrm{H}$ (cubic anti-perovskite type structure, space group $P m 3 m, a=406.313(1) \mathrm{pm}, \Delta \mathrm{V} / \mathrm{V}_{0}=3.9 \%$ ) was observed at temperatures of $320^{\circ} \mathrm{C}$ up to $730^{\circ} \mathrm{C}$. Depending mostly on temperature the reaction progress was followed by ex and in situ methods showing the existence of $\alpha-\mathrm{TlPd}_{3} \mathrm{H}_{\mathrm{x}}$ (tetragonal $\mathrm{ZrAl} \mathrm{l}_{3}$-type like metal atom lattice) and $\beta-\mathrm{TlPd} \mathrm{H}_{\mathrm{x}}(\mathrm{cubic}$ $\mathrm{AuCu}_{3}$-type like metal atom lattice) who are structurally related. $\mathrm{TlPd}_{3}$ as well as $\alpha-\mathrm{TlPd}_{3} \mathrm{H}_{\mathrm{x}}$ differ from $\beta-\mathrm{TlPd}_{3} \mathrm{H}_{\mathrm{x}}$ in having anti-phase boundaries 1/2 [110] which are removed during hydrogen uptake progress. Dehydrogenation experiments of the $\mathrm{TlPd}_{3} \mathrm{H}_{\mathrm{x}}$ phases under dynamic vacuum over 16 hours showed a small hydrogen release at around $125^{\circ} \mathrm{C}$ and total dehydrogenation at $230^{\circ} \mathrm{C}$.

\section{Acknowledgments}

This work has been supported by the Deutsche Forschungsgemeinschaft (grant Ko1803/2), the Institut Laue Langevin within the long term proposal LTP-5A-1 and by Saarland Universtity (PhD scholarship). We thank Thomas Hansen (ILL) for his support with the neutron diffraction experiments as well as Silvia Beetz and Hermann Recktenwald for technical assistance with the construction of the fittings for the gas pressure cell.

[1] T. B. Flanagan, F. A. Lewis, Z. Phys. Chem. Neue Folge 1961, 27, 104-111.

[2] F.A. Lewis, Platinum Met. Rev. 1982, 26, 20-27, $70-78$ and 121-128.

[3] L. Schlapbach, Hydrogen in Intermetallic Compounds I, Springer-Verlag, 1988, 1-10.

[4] G. Wiesinger, G. Hilscher, Handbook of Magnetic Materials (K. H. J. Buschow, Ed.), Elsevier, Amsterdam, 2008, Vol. 17, $293-456$.

[5] A. R. Miedema, K. H. J. Buschow, H. H. Van Mal, J. Less-Common Met. 1976, 49, 463-472.

[6] S. Miraglia, D. Fruchart, E. K. Hlil, S. S. M. Tavares, D. Dos Santos, J. Alloys Compd. 2001, 317-318, 77-82.

[7] R. Nakayama, T. Takeshita, J. Appl. Phys. 1993, 74, 2719-2724.

[8] P. Önnerud, Y. Andersson, R. Tellgren, P. Norblad, F. Bourée, G. André, Solid State Commun. 1997, 101, 433-437.

[9] H. Vehoff, in H. Wipf (Ed.), Hydrogen Materials III, Top. Appl. Phys. 1997, 73, 215-278.

[10] E. Akiba, Current Opinion in Solid State Mater. Sci. 1999, 4, 267-272.

[11] J. L Soubeyroux, D. Fruchart, A. S. Biris, Phys. B 1998, 241-243, 341-343.

[12] J.J. Reilly, R. H. Wiswall, Inorg. Chem. 1967, 6, 2220-2223 and 1968, 7, 2254-2256.

[13] R. Balasubramaniam, Scr. Metall. Mater. 1994, 30(7), 875-880.

[14] P. Kumar, M. Hareesh, R. Balasubramaniam, J. Alloys Compd. 1995, 217, 151-156.

[15] T. B. Flanagan, Y. Sakamoto, Platinum Met. Rev. 1993, 37, 26-37.

[16] T. B. Flanagan, H. Noh, J. Clewley, Pol. J. Chem. 1997, 71, 1725-1734.

[17] T. B. Flanagan, S. Luo, J. Phys. Chem. B 2006, 110, 8080-8086.

[18] R. Tellgren, Y. Andersson, I. Goncharenko, G. André, F. Bourée, I. Mirebeau, J. Solid State Chem. 2001, 161, 93-96.

[19] K. J. Baba, Y. Niki, Y. Sakamoto, J. Less-Common Met. 1991, 172-174, 246-253.

[20] J. P. Ahlzen, Y. Andersson, R. Tellgren, D. Rodic, Z. Phys. Chem. Neue Folge 1989, 163, 213-218.

[21] C. Wannek, B. Harbrecht, J. Solid State Chem. 2001, 159, 113-120.

[22] C. Wannek, Dissertation, Univ. Marburg 2001.

[23] H. Kohlmann, G. Renaudin, K. Yvon, C. Wannek, B. Harbrecht, J. Solid State Chem. 2005, 178, 1292-1300.

[24] H. Kohlmann, N. Kurtzemann, R. Weihrich, T. Hansen, Z. Anorg. Allg. Chem. 2009, 635, 2399-2405.

[25] C. Wannek, B. Harbrecht, Z. Anorg. Allg. Chem. 2007, 633, 1397-1402.

[26] K. Schubert, H. L. Lukas, H.-G. Meißner, S. Bhan, Z. Metallkde. 1959, 50, 534-540.

[27] S. Bhan, K. Schubert, J. Less-Common Met. 1969, 17, 73-90.

[28] C. Wannek, B. Harbrecht, Z. Anorg. Allg. Chem. 2000, 626, 1540-1544.

[29] H. Kohlmann, C. Ritter, Z. Naturforsch. B 2007, 62, 929-934.

[30] H. Kohlmann, C. Ritter, Z. Anorg. Allg. Chem. 2009, 635, 1573-1579.

[31] H. Kohlmann, J. Solid State Chem. 2010, 183, 367-372.

[32] H. H. Stadelmaier, W. K. Hardy, Z. Metallkde. 1961, 52, 391-396.

[33] K. Schubert, S. Bhan, T. K. Biswas, K. Frank, P. K. Panday, Naturwissenschaften 1968, 55, 542-543.

[34] S. Bhan, T. Gödecke, P. K. Panday, K. Schubert, J. Less-Common Met. 1968, 16, 415-425.

[35] H. Nowotny, K. Schubert, U. Dettinger, Z. Metallkde. 1946, 37,137-145.

[36] C. Zöllner, G. Thiele, M. Müllner, Z. Anorg. Allg. Chem. 1978, 443, 11-18.

[37] M. Müllner, G. Thiele, C. Zöllner, Z. Anorg. Allg. Chem. 1978, 443, 19-22. 
[38] J. Rodriguez-Carvajal, FullProf.2k, Version 4.50, Jan2009-ILL JCR, 2009.

[39] T. C. Hansen, P. F. Henry, H. E. Fischer, J. Torresgrossa, P. Convert, Meas. Sci. Technol. 2008, 19, 034001.

[40] P. F. Henry, M. T. Weller, C. C. Wilson, Chem. Commun. (Cambridge, U. K.) 2008, 1557-1559.

[41] V. P.Ting, P. F. Henry, C. C. Wilson, H. Kohlmann, M. T. Weller, Phys. Chem. Chem. Phys. 2010, in press.

[42] C. E. Messer, J. Eastman, R. G. Mers, A. Maeland, Inorg. Chem. 1964, 3, 776-778.

[43] W. Bronger, K. Jansen, P. Müller, J. Less-Common Met. 1990, 161, 299-302.

[44] H. Kohlmann, K. Yvon, J. Alloys Compds. 2000, 299, L16.

[45] H. Kohlmann, H. E. Fischer, K. Yvon, Inorg. Chem. 2001, 40, 2608-2613.

[46] K. Yvon, H. Kohlmann, B. Bertheville, Chimia 2001, 55, 505-509.

[47] K. Yvon, B. Bertheville, J. Alloys Compds. 2006, 425, 101-108.

[48] D. S. Schwarz, W. B. Yelon, R. R. Berliner, R. J. Lederich, S. M. L. Sastry, Acta Metall. Mater. 1991, $39,2799$.

[49] M. Vennström, A. Grechnev, O. Eriksson, Y. Andersson, J. Alloys Compds. 2004, 364, 127-131.

[50] H. Kohlmann, F. Müller, K. Stöwe, A. Zalga, H. P. Beck, Z. Anorg. Allg. Chem. 2009, 635, 1407-1411.

[51] G. Grosse, F. E. Wagner, V. E. Antonov, T. E. Antonova, J. Alloys Compds. 1997, 253-254, 339-342.

[52] Z.- C. Dong, J. D. Corbett, Inorg. Chem. 1995, 34, 5709-10.

[53] J. E. Schirber, B. Morosin, Phys. Rev. B: Condens. Matter 1975, 12, 117-118.

Received: ((will be filled in by the editorial staff)) Published online: ((will be filled in by the editorial staff)) 


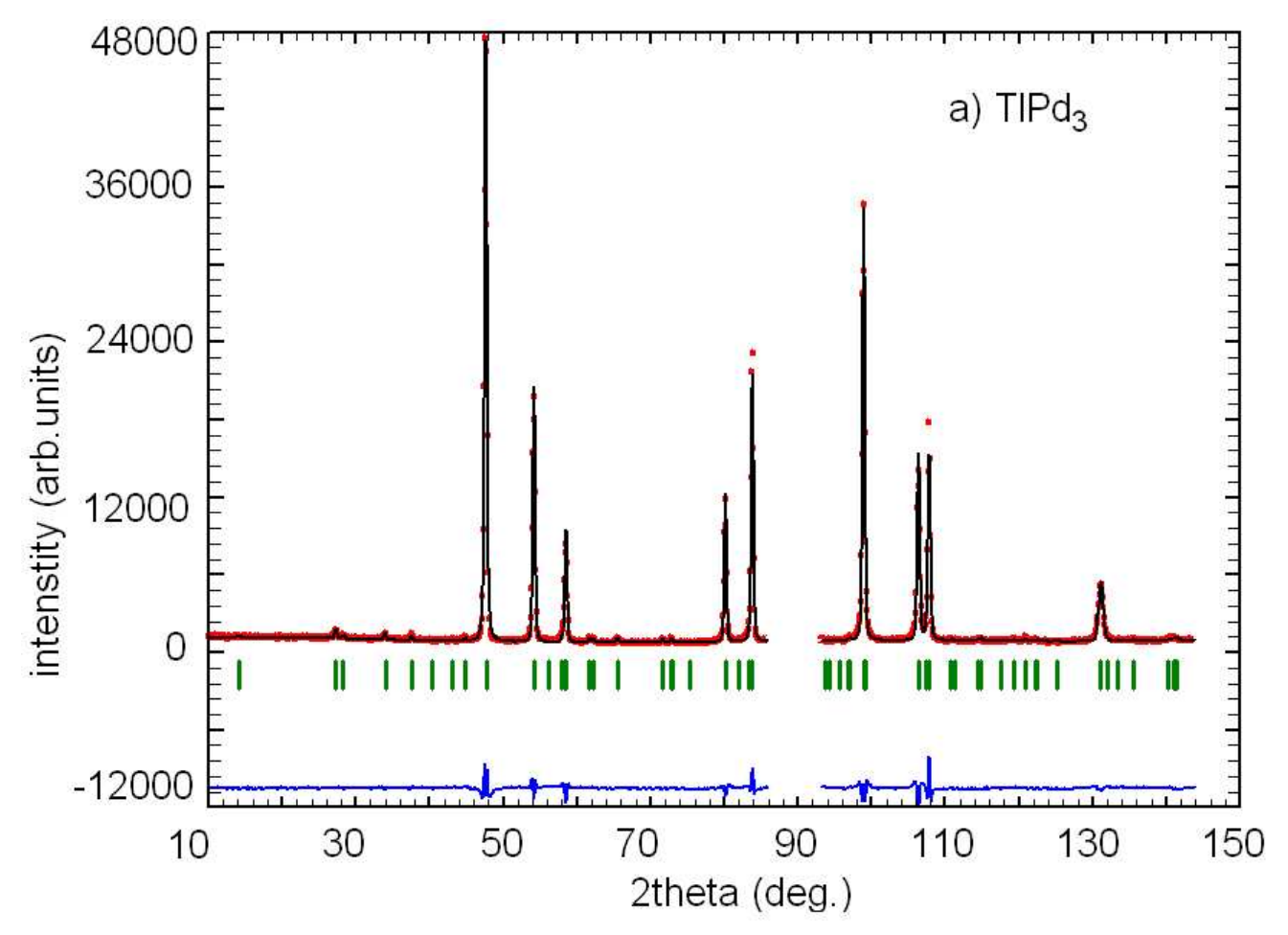

$228 \times 165 \mathrm{~mm}(96 \times 96$ DPI $)$ 


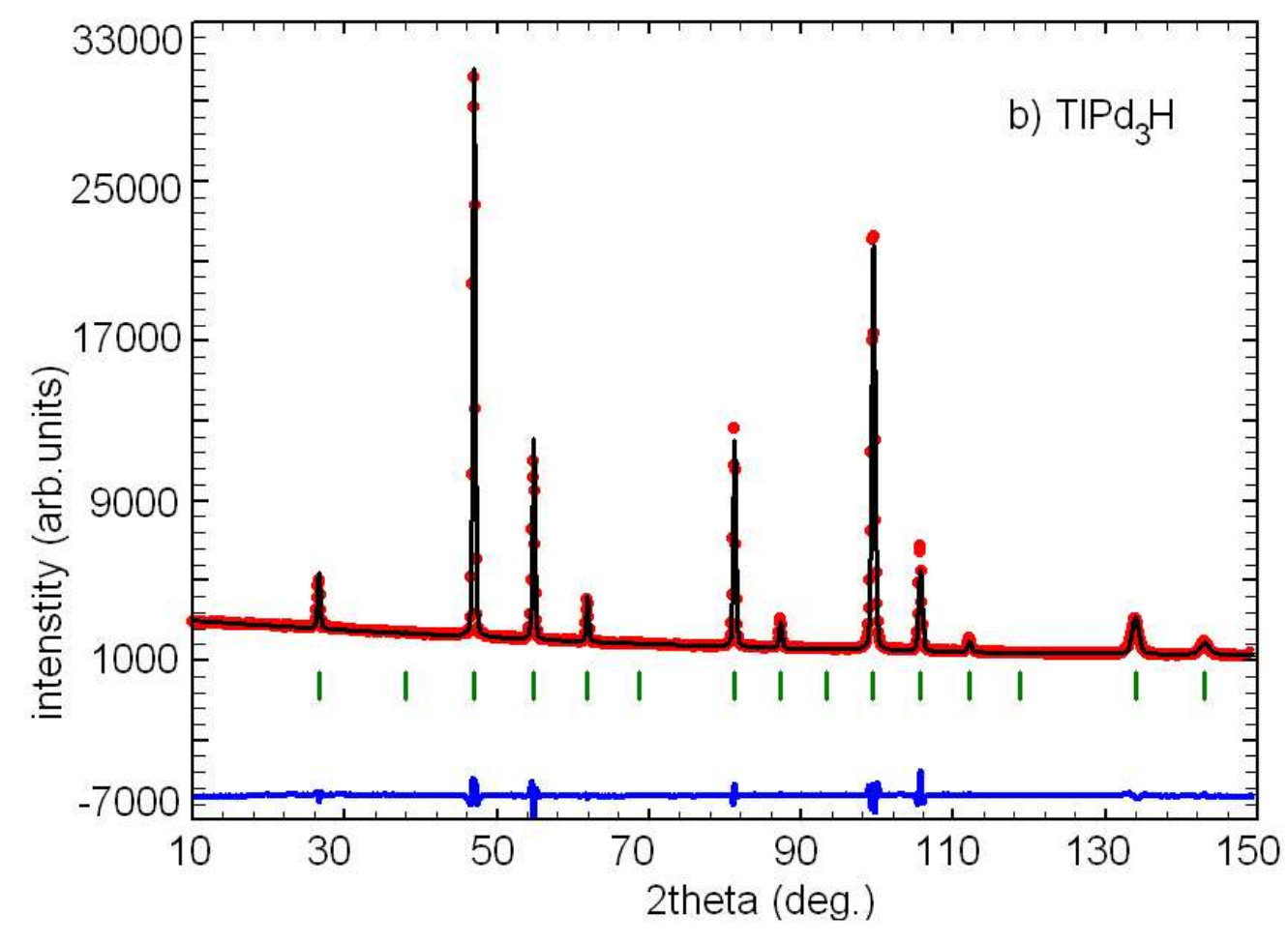

$224 \times 167 \mathrm{~mm}(96 \times 96$ DPI) 


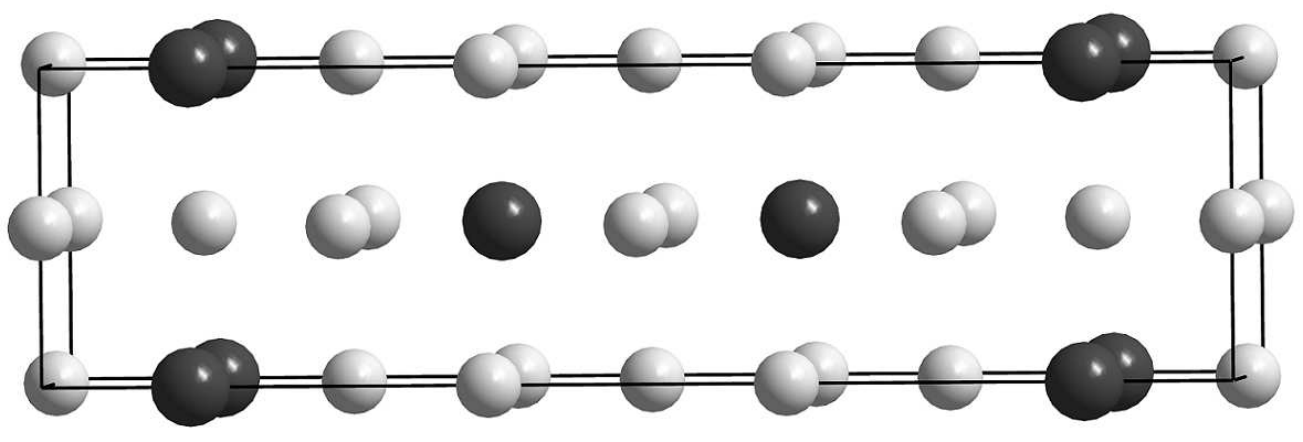

$311 \times 104 \mathrm{~mm}(96 \times 96$ DPI) 


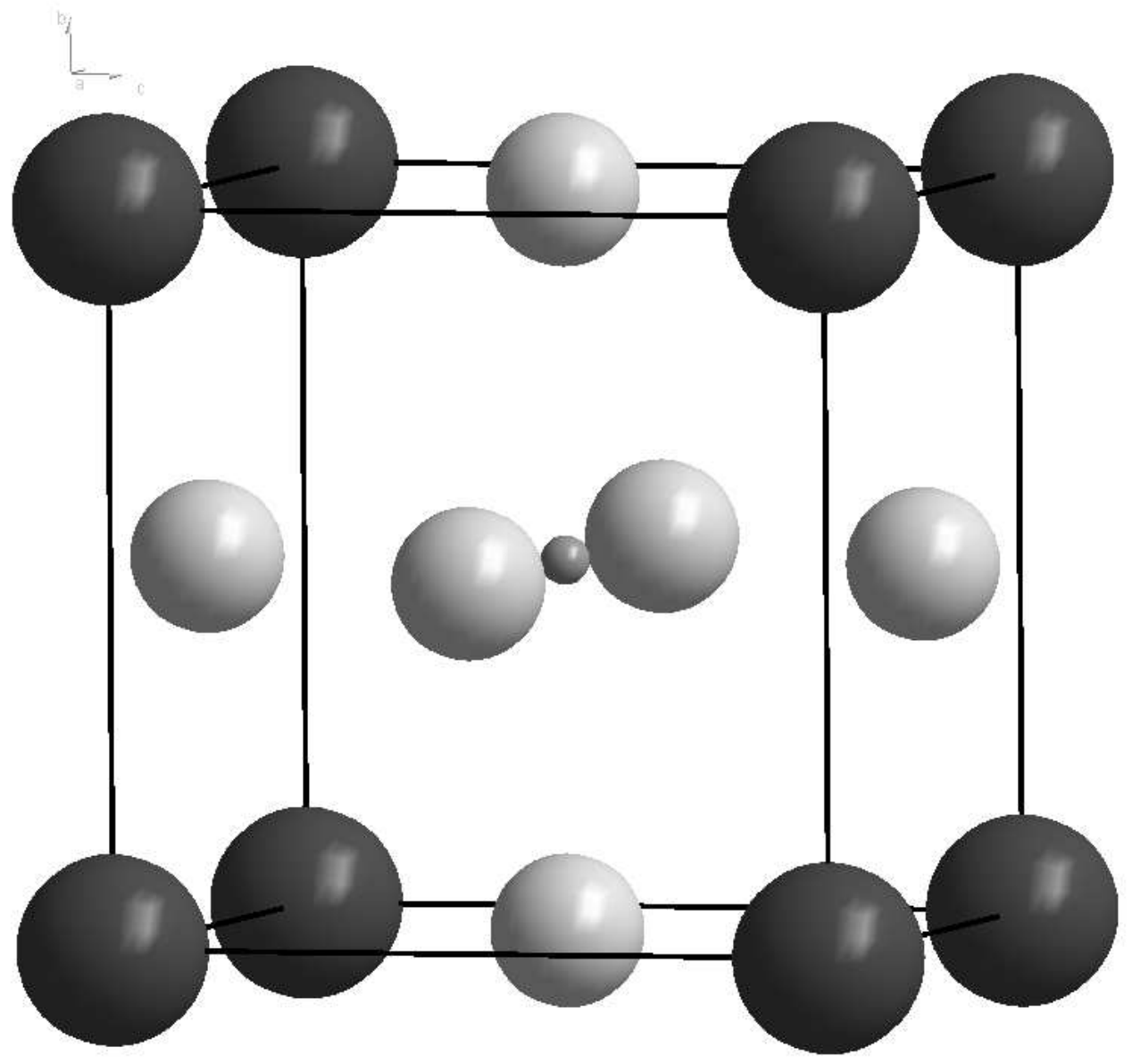

((Crystal structure of TIPd3H (cubic anti-perovskite type), dark grey spheres represent thallium, bright grey spheres palladium and small middle grey spheres hydrogen)) $203 \times 195 \mathrm{~mm}(96 \times 96 \mathrm{DPI})$ 


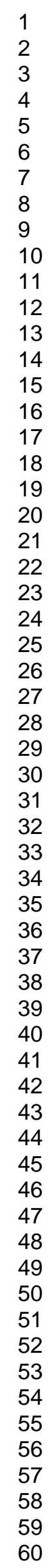

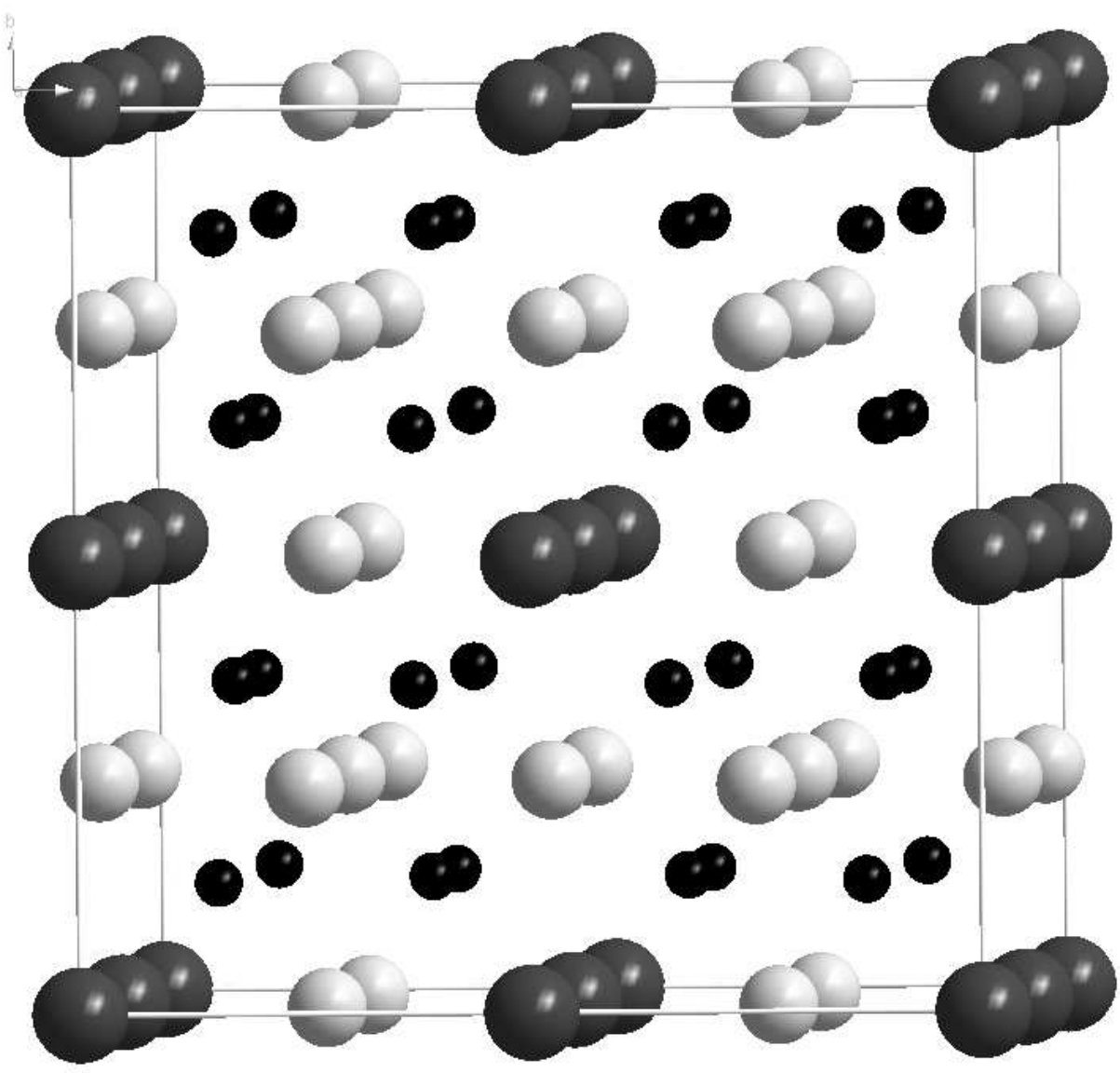

$203 \times 195 \mathrm{~mm}(96 \times 96$ DPI) 


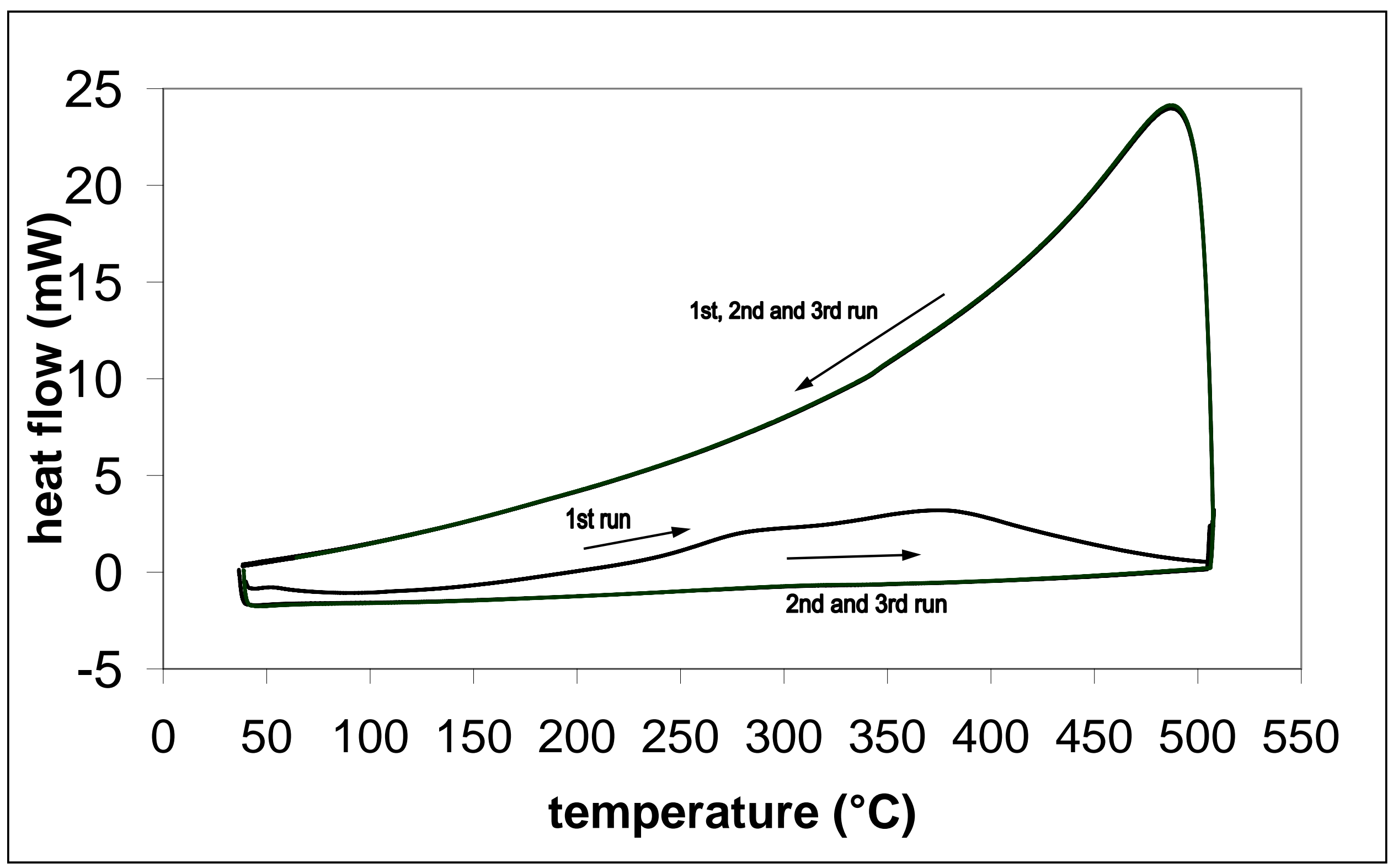


Table 1. ((Crystal structure parameters and atomic distances of $\mathrm{TlPd}_{3}$ at room temperature from neutron powder diffraction data space group I4/mmm (No.139): $\left.a=410.659(9) \mathrm{pm}, c=1530.28(4) \mathrm{pm}, V=258.068(11)^{*} 10^{6} \mathrm{pm}^{3}.\right)$ )

\begin{tabular}{|c|c|c|c|c|c|}
\hline Atom & Site & $\mathrm{x}$ & $\mathrm{y}$ & $\mathrm{Z}$ & $B_{\text {iso }} / 10^{4} \mathrm{pm}$ \\
\hline $\mathrm{Tl}$ & $4 e$ & 0 & 0 & $0.1240(3)$ & $0.67(5)$ \\
\hline Pd1 & $4 c$ & 0 & $1 / 2$ & 0 & $0.67(4)$ \\
\hline $\operatorname{Pd} 2$ & $4 d$ & 0 & $1 / 2$ & $1 / 4$ & $\mathrm{~B}_{\text {iso }}(\mathrm{Pd} 1)$ \\
\hline $\mathrm{Pd} 3$ & $4 e$ & 0 & 0 & $0.3778(5)$ & $\mathrm{B}_{\text {iso }}(\mathrm{Pd} 1)$ \\
\hline \multicolumn{4}{|c|}{ Pd1-Pd1: 290.4(1) pm } & \multicolumn{2}{|c|}{ Pd1-Tl: 279.6(3) pm } \\
\hline \multicolumn{4}{|c|}{ Pd1-Pd3: 277.7(5) pm } & \multicolumn{2}{|c|}{ Pd2-Tl: 281.7(3) pm } \\
\hline \multicolumn{4}{|c|}{ Pd2-Pd3: 283.6(3) pm } & \multicolumn{2}{|c|}{ Pd3-Tl: 290.4(1) pm } \\
\hline
\end{tabular}

$R_{\mathrm{p}}=0.054, R_{\mathrm{wp}}=0.072, R^{\prime}{ }_{\mathrm{p}}=0.122, R^{\prime}{ }_{\mathrm{wp}}=0.118, R_{\mathrm{Bragg}}=0.031$ Definition of R factors: $R_{\mathrm{p}}=\Sigma \mathrm{ly}_{\mathrm{i}}(\mathrm{obs})-\mathrm{y}_{\mathrm{i}}(\mathrm{calc}) \mid / \Sigma \mathrm{y}_{\mathrm{i}}(\mathrm{obs}) ; R_{\mathrm{wp}}=\left[\Sigma \mathrm{w}_{\mathrm{i}}\right.$

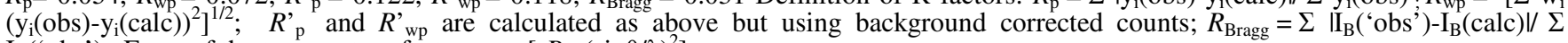
$\mathrm{I}_{\mathrm{B}}\left(\right.$ 'obs') . Form of the temperature factor: $\exp \left[-B_{\text {iso }}(\sin \theta / \lambda)^{2}\right]$. 
Table 2. ((Crystal structure parameters and atomic distances of $\mathrm{TlPd}_{3} \mathrm{H}$ at room temperature from neutron powder diffraction data space group Pm-3m (No.221): $\left.a=406.313(1) \mathrm{pm}, V=67.078(3) * 10^{6} \mathrm{pm}^{3}.\right)$ )

$\begin{array}{llllll}\text { Atom } & \text { Site } & \mathrm{x} & \mathrm{y} & \mathrm{z} & B_{\text {iso }} / 10^{4} \mathrm{pm} \\ \mathrm{Tl} & 1 a & 0 & 0 & 0 & 0.47(5) \\ \mathrm{Pd} & 3 c & 1 / 2 & 1 / 2 & 0 & 0.50(3) \\ \mathrm{H} & 1 b & 1 / 2 & 1 / 2 & 1 / 2 & 2.6(2)\end{array}$

Pd-H: 203.2(1) pm Pd-Tl: 287.(1) pm

$R_{\mathrm{p}}=0.021, R_{\mathrm{wp}}=0.033, R_{\mathrm{p}}^{\prime}=0.143, R_{\mathrm{wp}}^{\prime}=0.103, R_{\mathrm{Bragg}}=0.045$. Defintion of $R_{\mathrm{p}}, R_{\mathrm{wp}}, R_{\mathrm{p}}{ }_{\mathrm{p}}, R_{\mathrm{wp}}{ }_{\mathrm{wp}}, R_{\mathrm{Bragg}}$ and form of the temperature factor see Table 1 


\begin{tabular}{|c|c|c|c|c|c|c|c|c|c|}
\hline $\begin{array}{l}\text { starting } \\
\text { material }\end{array}$ & $\begin{array}{l}\text { T, } \\
\text { time }\end{array}$ & $\mathbf{P}$ (gas) & $\begin{array}{l}\text { Mass } \\
\%\end{array}$ & $\begin{array}{l}\text { Product } \\
\text { phases }\end{array}$ & $\begin{array}{l}\text { Metal } \\
\text { sub- } \\
\text { lattice }\end{array}$ & $\mathbf{a}[\mathrm{pm}]$ & c [pm] & $\begin{array}{l}\text { V (f.u. } \\
\left.\text { TIPd }_{3}\right) \\
{\left[10^{6} \mathbf{p m}^{3}\right]}\end{array}$ & $\begin{array}{l}\Delta \mathrm{V} / \mathrm{V}_{0} \\
{[\%]}\end{array}$ \\
\hline \multirow[t]{3}{*}{$\begin{array}{l}\text { elements } \\
\text { TI, Pd }\end{array}$} & $\begin{array}{l}600^{\circ} \mathrm{C} \\
160 \mathrm{~h}\end{array}$ & $\begin{array}{l}\text { evacuated } \\
\text { silica tube }\end{array}$ & 100 & $\mathrm{TlPd}_{3}$ & $\mathrm{ZrAl}_{3}$ & $410.403(2)$ & $1530.56(1)$ & $64.448(3)$ & -0.1 \\
\hline & $*$ & $*$ & $*$ & $*$ & $*$ & $410.659(9)$ & $1530.28(4)$ & $64.515(1)$ & $\mathbf{0}=\mathbf{V}_{\mathbf{0}}$ \\
\hline & $\begin{array}{l}600^{\circ} \mathrm{C} \\
60 \mathrm{~h}\end{array}$ & $\begin{array}{l}\text { evacuated } \\
\text { silica tube }\end{array}$ & 100 & $\mathrm{TlPd}_{3}$ & $\mathrm{ZrAl}_{3}$ & $411.400(3)$ & $1526.89(2)$ & $64.607(4)$ & +0.1 \\
\hline \multirow[t]{6}{*}{$\mathbf{T I P d}_{3}$} & $\begin{array}{l}730^{\circ} \mathrm{C} \\
12 \mathrm{~h}\end{array}$ & $\mathrm{H}_{2}$, lbar & 100 & $\beta-T l P d_{3} H$ & $\mathrm{AuCu}_{3}$ & 406.104(4) & & $66.975(1)$ & +3.8 \\
\hline & $\begin{array}{l}320^{\circ} \mathrm{C} \\
1 \mathrm{~h}\end{array}$ & $\begin{array}{l}\mathrm{H}_{2} \text {, DSC } \\
1.5 \mathrm{bar}\end{array}$ & 100 & $\beta-T l P d_{3} H$ & $\mathrm{AuCu}_{3}$ & $406.195(5)$ & & $67.020(1)$ & +3.9 \\
\hline & $\begin{array}{l}500^{\circ} \mathrm{C} \\
1 \mathrm{~h}\end{array}$ & $\begin{array}{l}\mathrm{H}_{2} \text {, DSC } \\
1.5 \mathrm{bar}\end{array}$ & 100 & $\beta-T l P d_{3} H$ & $\mathrm{AuCu}_{3}$ & $406.252(2)$ & & $67.048(1)$ & +3.9 \\
\hline & $\begin{array}{l}500^{\circ} \mathrm{C} \\
10 \mathrm{~h}\end{array}$ & $\mathrm{H}_{2}, 1$ bar & 100 & $\beta-T l P d_{3} H$ & $\mathrm{AuCu}_{3}$ & $406.272(4)$ & & $67.058(1)$ & +3.9 \\
\hline & $*$ & $*$ & $*$ & $*$ & $*$ & $406.313(1)$ & & 67.078(3) & +3.9 \\
\hline & $\begin{array}{l}730^{\circ} \mathrm{C} \\
12 \mathrm{~h}\end{array}$ & $\begin{array}{l}7.5 \% \mathrm{H}_{2} / \mathrm{Ar} \\
1 \mathrm{bar}\end{array}$ & $\begin{array}{l}86 \\
14\end{array}$ & $\begin{array}{l}\alpha-\operatorname{TlPd}_{3} H \\
\beta-T l P d_{3} H\end{array}$ & $\begin{array}{l}\mathrm{ZrAl}_{3} \\
\mathrm{AuCu}_{3}\end{array}$ & $\begin{array}{l}411.133(5) \\
405.84(1)\end{array}$ & $1536.27(3)$ & $\begin{array}{l}64.919(7) \\
66.844(3)\end{array}$ & $\begin{array}{l}+0.6 \\
+3.6\end{array}$ \\
\hline \multirow[t]{3}{*}{$\mathrm{TIPd}_{3} \mathrm{O}_{4}$} & $\begin{array}{l}730^{\circ} \mathrm{C} \\
12 \mathrm{~h}\end{array}$ & $\mathrm{~N}_{2}, 1 \mathrm{bar}$ & 100 & $\mathrm{TlPd}_{3}$ & $\overline{\mathrm{ZrAl}_{3}}$ & $410.454(3)$ & $1531.05(1)$ & $64.485(4)$ & -0.1 \\
\hline & $\begin{array}{l}730^{\circ} \mathrm{C} \\
12 \mathrm{~h}\end{array}$ & $\begin{array}{l}7.5 \% \mathrm{H}_{2} / \mathrm{Ar} \\
1 \mathrm{bar}\end{array}$ & $\begin{array}{l}18 \\
82\end{array}$ & $\begin{array}{l}\alpha-\operatorname{TlPd}_{3} H \\
\beta-\operatorname{TlPd}_{3} H\end{array}$ & $\begin{array}{l}\mathrm{ZrAl}_{3} \\
\mathrm{AuCu}_{3}\end{array}$ & $\begin{array}{l}410.34(3) \\
406.077(6)\end{array}$ & $1544.5(2)$ & $\begin{array}{l}65.018(4) \\
66.962(2)\end{array}$ & $\begin{array}{l}+0.8 \\
+3.8\end{array}$ \\
\hline & $\begin{array}{l}730^{\circ} \mathrm{C} \\
12 \mathrm{~h}\end{array}$ & $\mathrm{H}_{2}, 1 \mathrm{bar}$ & 100 & $\beta-T l P d_{3} H$ & $\mathrm{AuCu}_{3}$ & $406.092(2)$ & & $66.969(1)$ & +3.8 \\
\hline $\begin{array}{l}5 \text { phase } \\
\text { mixture }\end{array}$ & $\begin{array}{l}730^{\circ} \mathrm{C} \\
12 \mathrm{~h}\end{array}$ & $\begin{array}{l}7.5 \% \mathrm{H}_{2} / \mathrm{Ar} \\
1 \mathrm{bar}\end{array}$ & $\begin{array}{l}64 \\
36\end{array}$ & $\begin{array}{l}\alpha-\operatorname{TlPd}_{3} H \\
\beta-T l P d_{3} H\end{array}$ & $\begin{array}{l}\mathrm{ZrAl}_{3} \\
\mathrm{AuCu}_{3}\end{array}$ & $\begin{array}{l}411.351(8) \\
405.980(6)\end{array}$ & $1535.18(4)$ & $\begin{array}{l}64.943(1) \\
66.914(2)\end{array}$ & $\begin{array}{l}+0.7 \\
+3.7\end{array}$ \\
\hline \multirow[t]{2}{*}{$\begin{array}{l}\alpha-\operatorname{TIPd}_{3} \mathrm{H} \\
\beta-\mathrm{TIPd}_{3} \mathrm{H}\end{array}$} & $\begin{array}{l}120- \\
130^{\circ} \mathrm{C} \\
16 \mathrm{~h}\end{array}$ & vacuum & $\begin{array}{l}55 \\
45\end{array}$ & $\begin{array}{l}\alpha-\operatorname{TlPd}_{3} H \\
\beta-\operatorname{TlPd}_{3} H\end{array}$ & $\begin{array}{l}\mathrm{ZrAl}_{3} \\
\mathrm{AuCu}_{3}\end{array}$ & $\begin{array}{l}410.695(6) \\
405.804(6)\end{array}$ & 1534.94(3) & $\begin{array}{l}64.725(8) \\
66.827(2)\end{array}$ & $\begin{array}{l}+0.3 \\
+3.6\end{array}$ \\
\hline & $\begin{array}{l}230^{\circ} \mathrm{C} \\
16 \mathrm{~h}\end{array}$ & vacuum & 100 & $\mathrm{TlPd}_{3}$ & $\mathrm{ZrAl}_{3}$ & $410.640(2)$ & $1529.15(2)$ & $64.463(3)$ & -0.1 \\
\hline \multirow[t]{2}{*}{$\beta$-TIPd ${ }_{3} \mathrm{H}$} & $\begin{array}{l}120- \\
130^{\circ} \mathrm{C} \\
16 \mathrm{~h}\end{array}$ & vacuum & 100 & $\beta-T l P d_{3} H$ & $\mathrm{AuCu}_{3}$ & $406.033(3)$ & & $66.939(1)$ & +3.6 \\
\hline & $\begin{array}{l}230^{\circ} \mathrm{C} \\
16 \mathrm{~h}\end{array}$ & vacuum & 100 & $\mathrm{TlPd}_{3}$ & $\mathrm{ZrAl}_{3}$ & $410.635(3)$ & $1529.23(2)$ & $64.465(4)$ & -0.1 \\
\hline
\end{tabular}

